Vol.2 No. 01Hal. $46-52$

April 2019

\title{
Gambaran Pengetahuan, Sikap, dan Tindakan Pelajar Tentang Makanan Cepat Saji (Fast Food) di Mts Al-Manar Medan
}

\author{
dr. Zaim Anshari, M.Pd, M.Kes
}

Dosen Program Studi Kedokteran FK UISU

zaimanshari@fk.uisu.ac.id

\begin{abstract}
ABSTRAK
Makanan siap saji adalah istilah untuk makanan yang dapat disiapkan dan dilayankan dengan cepat. Penelitian ini dilakukan untuk mengetahui gambaran dan distribusi frekuensi pengetahuan, sikap dan tindakan pelajar-pelajar setingkat MTs tentang makanan cepat saji (fast food). Penelitian di lakukan di MTs Al-Manar Medan. Jenis penelitian ini deskriptif dengan pengambilan data kuantitatif, diambil 69 sampel responden yang mengisi kuesioner. Penelitian dilakukan pada bulan Desember tahun 2018. Berdasarkan hasil penelitian dari 69 responden terdapat43 orang $(62,3 \%)$ berjenis kelamin laki-laki dan 26 orang $(37,7 \%)$ berjenis kelamin perempuan. Terdapat 69 responden berumur paling banyak 14 tahun sebanyak 26 responden(37,7\%), didapatkan hasil sebagian besar responden memiliki pengetahuan baik tentang makanan cepat saji (Fast Food) yaitu sebanyak 33 orang $(47,8 \%)$, sebagian besar responden memiliki sikap baik terhadap makanan cepat saji (Fast Food) yaitu sebanyak 38 orang $(55,1 \%)$, sebagian besar responden memiliki frekuensi konsumsi sering dalam mengonsumsi makanan cepat saji (Fast Food) sebanyak 41 orang $(59,4 \%)$, sebagian besar responden yaitu 33 orang $(47,8 \%)$ yang memiliki pengetahuan baik, ada 20 orang $(29,0 \%)$ yang mempunyai frekuensi konsumsi makanan cepat saji (fast food) sering. Kemudian dari 38 orang $(55,1 \%)$ yang memiliki sikap baik terhadap makanan cepat saji (fast food), ada 25 orang $(36,2 \%)$ yang mempunyai frekuensi konsumsi makanan cepat saji sering. Untuk mengurangi dampak makanan cepat saji sebaiknya responden mengimbanginya dengan makanan tinggi serat seperti sayuran dan buah-buahan, serta rajin berolahraga.
\end{abstract}

Kata Kunci : Fast Food, Pengetahuan, Sikap, Tindakan, Pelajar

\begin{abstract}
Fast food is a term for food that can be prepared and served quickly. This study was conducted to determine the description and frequency distribution of knowledge, attitudes and actions of MTs-level students about fast food. The research was conducted at the Al-Manar MTs in Medan. This type of research is descriptive with quantitative data collection, taking 69 samples of respondents who filled out the questionnaire. The study was conducted in December 2018. Based on the results of the study of 69 respondents there were 43 people $(62.3 \%)$ male sex and 26 people $(37.7 \%)$ female sex. There were 69 respondents aged at most 14 years as many as 26 respondents (37.7\%), the results showed that most respondents had good knowledge about fast food (Fast Food) as many as 33 people (47.8\%), most respondents had an attitude good for fast food (Fast Food) as many as 38 people (55.1\%), most of the respondents have frequent consumption frequency in consuming fast food (Fast Food) as many as 41 people $(59.4 \%)$, most of the respondents are 33 people $(47.8 \%)$ who have good knowledge, there are 20 people $(29.0 \%)$ who have frequent consumption of fast food (fast food). Then from 38 people $(55.1 \%)$ who have a good attitude towards fast food (fast food), there are 25 people $(36.2 \%)$ who have frequent consumption of fast food. To reduce the impact of fast food, respondents should balance it with high-fiber foods such as vegetables and fruits, and diligently exercise.
\end{abstract}

Keywords : Fast Food, Knowledge, Attitudes, Actions, Students 
Anshari Z : Gambaran Pengetahuan, Sikap, dan Tindakan Pelajar, Tentang Makanan Cepat Saji (Fast Food) di MTs Al-Manar Medan

\section{PENDAHULUAN}

\section{Latar Belakang}

World Health Organization menyatakan bahwa satu dari 10 (sepuluh) anak di dunia mengalami kegemukan. Peningkatan obesitas pada anak dan remaja sejajar dengan orang dewasa. Menurut World Health Organization pada tahun 2008 terdapat $>1.4$ milyar orang dewasa berumur $>20$ tahun ke atas yang kelebihan berat badan dan setidaknya terdapat 200 juta laki-laki dan >300 juta perempuan yang obese. Penelitian di Michigan, Amerika Serikat menunjukkan perbandingan obesitas meningkat setidaknya 50\% pada orang yang mengkonsumsi makanan cepat saji (fast food) $\geq 3 \mathrm{x} /$ minggu dibandingkan dengan yang hanya mengkonsumsi < 1x /minggu.Berkat kemajuan teknologi, berbagai jenis produk pangan baru berhasil dipasarkan oleh industri, misalnya makanan instan siap santap atau siap masak, minuman penyegar berkarbonat, makanan berkalori rendah, dan makanan cepat (fast food). Dampak dari arus globalisasi yang paling nyata terlihat pada penduduk di perkotaan adalah gaya hidup konsumsi pangan, termasuk gaya hidup dalam memilih berbagai makanan dari jenis pangan yang dikonsumsi. Perubahan gaya hidup dalam konsumsi pangan ini terutama dipicu oleh perbaikan/peningkatan pendapatan, kesibukan kerja yang tinggi, dan promosi produk pangan ala Barat, utamanya fast food, namun tidak diimbangi dengan peningkatan pengetahuan dan kesadaran gizi. Meningkatnya taraf hidup (kesejahteraan) masyarakat, pengaruh promosi melalui iklan, serta kemudahan informasi, dapat menyebabkan perubahan gaya hidup dan timbulnya kebutuhan psikogenik baru di kalangan masyarakat ekonomi menengah ke atas. Tingginya pendapatan yang tidak diimbangi pengetahuan gizi yang cukup, akan menyebabkan seseorang menjadi sangat konsumtif dalam pola makannya sehari-hari, sehingga pemilihan suatu bahan makanan lebih didasarkan kepada pertimbangan selera dibandingkan aspek gizi. Kecenderungan untuk mengonsumsi makanan impor, terutama jenis siap santap (fast food), seperti ayam goreng, pizza, hamburger dan lain-lain, telah meningkat tajam terutama di kalangan generasi muda dan kelompok masyarakat menengah ke atas. Selanjutnya kolompok warga kota yang berpenghasilan mapan, dalam konsumsi pangan sehari-hari selalu selera sentris, gengsi sentris dan ekonomi sentris. Selera sentris adalah gaya konsumsi pangan yang terlalu berorientasi pada unsur selera. Dalam hal ini lokasi tempat makan dan jenis pangan yang dihidangkan menjadi pertimbangan utama, sedangkan pertimbangan gizi kurang mendapat perhatian. Karena terpukau oleh kenikmatan menyantap pangan, mudharat kelebihan konsumsi terlupakan, sehingga timbul masalah gizi lebih. Gengsi sentris merupakan gaya konsumsi pangan yang berorientasi pada pangan yang bergengsi tinggi seperti pangan impor, khususnya fast food. Pangan tradisional yang lebih menjamin masukan gizi seimbang tidak lagi menjadi pilihan kelompok gizi sentris, karena makanan tradisional dinilai tidak bergengsi. Bila di Negara-negara Barat terdapat gerakan back to nature, yaitu gerakan mengkonsumsi pangan yang masih segar dan alami dengan komposisi gizi yang seimbang, maka dikota-kota besar di Indonesia justru terjadi arus balik, yaitu menjadikan fast food sebagai gaya konsumsi yang trendy dan meninggalkan pola konsumsi yang seimbang. Pada perayaan peristiwa penting (hari ulang tahun, promosi, dll) masyarakat kota lebih memilih makanan di restoran fast food daripada nasi tumpeng atau gado-gado yang tradisional. Masalah gizi lebih mulai muncul di Indonesia pada era tahun 1990-an, di saat gaya hidup fast food mulai memasuki wilayah Indonesia. Peningkatan pendapatan kelompok tertentu, terutama di perkotaan, menyebabkan perubahan dalam gaya hidup terutama pola makan. Pola makan tradisional yang tadinya tinggi karbohidrat serta serat kasar dan rendah lemak berubah ke pola makan baru yang rendah karbohidrat dan serat kasar serta tinggi lemak (fast food), sehingga menggeser mutu makanan kearah tidak seimbang. ${ }^{4}$ Hasil RISKESDAS pada tahun 2013 menunjukkan bahwa prevalensi gemuk pada remaja umur 13-15 tahun di Indonesia sebesar 10,8 persen, 
Anshari Z : Gambaran Pengetahuan, Sikap, dan Tindakan Pelajar, Tentang Makanan Cepat Saji (Fast Food) di MTs Al-Manar Medan

terdiri dari 8,3 persen gemuk dan 2,5 persen sangat gemuk (obesitas). Bahwa 69\% masyarakat kota di Indonesia mengonsumsi fast food yaitu 33\% menyatakan makan siang sebagai waktu yang tepat untuk makan di restoran fast food, 25\% untuk makan malam, 9\% menyatakan sebagai makanan selingan dan $2 \%$ memilih untuk memilih untuk makan pagi. Hal tersebut diperkirakan akan semakin berkembang sesuai dengan meningkatnya tingkat konsumsi makanan fast food di Indonesia. Berdasarkan penelitian yang dilakukan Khoimsyah didapatkan bahwa pengunjung restoran makanan cepat saji rata-rata merupakan remaja berpendidikan SMP dan SMU. Perubahan konsumsi makanan pada remaja tidak lepas juga dari peranan sosial ekonomi, gaya hidup, eksposur iklan di media televisi. Tingkat pengetahuan gizi remaja juga mempunyai pengaruh terhadap sikap dan perilakunya dalam memilih makanan yang akan dikonsumsinya. Penelitian mengenai fast food bahwa fried chicken dan french fries, sudah menjadi jenis makanan yang biasa dikonsumsi pada waktu makan siang atau makan malam remaja di enam kota besar di Indonesia seperti di Jakarta, Bandung, Semarang, Yogyakarta, Surabaya, dan Denpasar. Menurut penelitian tersebut 15-20\% dari 471 remaja di Jakarta mengonsumsi fried chicken dan burger sebagai makan siang dan 1-6\% mengonsumsi hotdog, pizza dan spaghetti. Bila makanan tersebut dikonsumsi secara terus-menerus dan berlebihan dapat mengakibatkan gizi lebih. Umumnya remaja rata-rata mengunjungi restoran cepat saji (fast food) dua kali seminggu. Penelitian yang dilakukan oleh Ratna tahun 2008 didapatkan hasil frekuensi konsumsi fast food pada remaja SMA Depok lebih dari dua kali per minggu sebanyak 36,1 $\%$ dan penelitian yang dilakukan Mardatillah pada tahun yang sama menunjukkan hasil frekuensi konsumsi fast food lebih dari dua kali dalam seminggu sebanyak 36,8\%. Hal ini juga didukung dengan hasil penelitian oleh Risa, dkk tahun 2009 pada remaja SMA Palembang frekuensi konsumsi fast food yang lebih dari tiga kali per minggu sebanyak sebanyak 52,2\%. Perilaku makan sehat untuk remaja adalah sama pentingnya dengan perubahan fisik selama masa remaja dan hal ini biasanya berpengaruh pada gizi yang dibutuhkan remaja. Remaja biasanya menjadi merasa bebas dalam memutuskan memilih makanan sesuai dengan keinginannya. Remaja cenderung lebih banyak makan di luar rumah juga banyak terpengaruh oleh peer groupnya. Remaja lebih suka mengonsumsi makanan yang sebenarnya termasuk tipe makanan junk food (misalnya: soft drink, fast food, makanan kemasan). Penelitian yang di lakukan mengenai Pengetahuan, sikap, dan tindakan mahasiswa fakultas kedokteran Universitas Sumatera Utara tentang konsumsi makanan cepat saji (fast food). Hasil penelitian menunjukkan pengetahuan mahasiswa tentang konsumsi makanan cepat saji mayoritas pada kategori baik (86,3\%), sikap mahasiswa pada kategori baik $(62,1 \%)$ dan tindakan mahasiswa Fakultas Kedokteran USU tentang konsumsi makanan cepat saji berada pada frekuensi konsumsi sangat sering yaitu 37,9\%. Makanan berkadar lemak tinggi dan berkadar serat rendah seperti makananmakanan fast food dan makanan Eropa lainnya, dapat menyebabkan terganggunya aktivitas enzim di usus besar yang meningkatkan risiko terjadinya kanker usus besar. Peneliti belum menemukan adanya penelitian tentang Gambaran pengetahuan, sikap, dan tindakan tentang makanan cepat saji (fast food) di kalangan pelajar SMP, terutama di MTs Al-Manar. Peneliti merasa perlu mengadakan penelitian untuk mengetahui Gambaran pengetahuan, sikap, dan tindakan pelajar MTs Al-Manar tentang makanan cepat saji (fast food).

\section{Perumusan Masalah}

Bagaimanakah gambaran pengetahuan, sikap dan tindakan pelajar MTs Al-Manar tentang makanan cepat saji (fast food)? 
Anshari Z : Gambaran Pengetahuan, Sikap, dan Tindakan Pelajar, Tentang Makanan Cepat Saji (Fast Food) di MTs Al-Manar Medan

\section{Tujuan Penelitian}

Mengetahui gambaran pengetahuan, sikap dan tindakan pelajar-pelajar setingkat MTs tentang makanan cepat saji (fast food), mengetahui distribusi frekuensi responden berdasarkan jenis kelamin dan usia, mengetahui distribusi frekuensi pengetahuan, sikap dan tindakan pelajar MTs Al-Manar tentang makanan cepat saji (fast food), serta untuk mengetahui hubungan antara pengetahuan dengan tindakan dan sikap dengan tindakan.

\section{Manfaat Penelitian}

Manfaat yang diharapkan dalam penelitian ini adalah untuk mengetahui hasil dari analisis lapangan mengenai gambaran pengetahuan, sikap, dan tindakan pelajar tentang makanan cepat saji (fast food) di MTs Al-Manar Medan.

\section{METODE PENELITIAN}

Ditinjau dari tujuan penelitian akan dicapai, penelitian ini menggunakan penelitian deskriptif yang digunakan untuk menggambarkan hasil penelitian, tetapi tidak digunakan untuk membuat kesimpulan yang lebih luas dengan pengambilan data menggunakan data kuantitatif, yaitu, data yang berbentuk angka.

\section{HASIL DAN PEMBAHASAN}

Proses pengambilan data untuk penelitian ini telah dilakukan dengan menggunakan alat bantu berupa kuesioner yang dibagikan kepada responden yang telah setuju untuk mengisi kuesioner yang berisi beberapa pertanyaan tentang makanan cepat saji (Fast Food). Hasil yang telah terkumpul kemudian diolah datanya menggunakan bantuan perangkat lunak statistik.

Penelitian ini dilakukan di MTs Al-Manar Medan dengan alamat Jalan Karya Bakti Nomor 34 yang berlokasi di Kelurahan Pangkalan Mansyur, Kecamatan Medan Johor, kota Medan, Provinsi Sumatera Utara. Sekolah ini mempunyai 8 ruang kelas yang terdiri dari 3 ruang kelas 7, 2 ruang kelas 8 dan 3 ruang kelas 9, ruang guru dan kantin, berada satu halaman dengan Pesantren Al-Manar, SMP Swasta Al-Manar, SMA Al-Manar, SMK Farmasi, dan kampus Fakultas Kedokteran UISU.

Responden yang menjadi sampel dalam penelitian ini adalah siswa dan siswi dari sekolah MTs Al-Manar Medan. Jumlah responden yang ikut terlibat dalam penelitian ini adalah sebanyak 69 orang, dengan jenis kelamin laki-laki dan perempuan.

Tabulasi Silang S ikap terhadap Frekuensi Konsumsi Makanan Cepat Saji (fast food)

\begin{tabular}{|c|c|c|c|c|c|c|c|c|}
\hline \multirow{2}{*}{$\begin{array}{c}\text { Sikap } \\
\text { Responden }\end{array}$} & \multicolumn{6}{|c|}{ Frekuensi Konsumsi Makanan Cepat Saji } & \multicolumn{3}{c|}{ Jumlah } \\
\cline { 2 - 8 } & \multicolumn{2}{|c|}{ Sangat Sering } & \multicolumn{2}{c|}{ Sering } & \multicolumn{2}{c|}{ Jarang } & \multicolumn{2}{c|}{} \\
\cline { 2 - 9 } & n & $\%$ & n & \% & n & \% & n & $\%$ \\
\hline Rendah & 2 & 2.9 & 0 & 0 & 0 & 0 & 2 & 2,9 \\
\hline Sedang & 5 & 7,2 & 16 & 23,2 & 8 & 11,6 & 29 & 42,0 \\
\hline Baik & 4 & 5,8 & 25 & 36,2 & 9 & 13,0 & 38 & 55,1 \\
\hline
\end{tabular}


Anshari Z : Gambaran Pengetahuan, Sikap, dan Tindakan Pelajar, Tentang Makanan Cepat Saji (Fast Food) di MTs Al-Manar Medan

Berdasarkan tabel 4.7 didapatkan hasil bahwa responden yang memiliki sikap baik terhadap makanan cepat saji cenderung memiliki frekuensi konsumsi makanan cepat saji sering, dimana dari 38 orang responden yang memiliki sikap baik, ada 25 orang yang sering mengonsumsi makanan cepat saji. Responden yang memiliki sikap sedang terhadap makanan cepat saji masih memiliki frekuensi konsumsi makanan cepat saji sering, dimana dari 29 orang responden, ada 16 orang yang sering mengonsumsi makanan cepat saji. Responden yang memiliki sikap rendah terhadap makanan cepat saji memiliki frekuensi konsumsi makanan cepat saji sangat sering, dimana dari 2 orang responden, semuanya sangat sering mengonsumsi makanan cepat saji. Responden yang digunakan dalam penelitian ini adalah pelajar MTs Al-Manar Medan yaitu sebanyak 43 responden $(62,3 \%)$ yang memiliki jenis kelamin laki-laki dan sisanya sebanyak 26 responden $(37,7)$ memiliki jenis kelamin perempuan, dengan total responden berjumlah 69 orang. Berdasarkan hasil dari penelitian yang telah dilakukan pada pelajar MTs Al-Manar mengenai pengetahuan, sikap, dan tindakan pelajar terhadap makanan cepat saji (fast food) dapat dijelaskan sebagai berikut:

\section{Pengetahuan Pelajar Tentang Makanan Cepat Saji (Fast Food)}

Berdasarkan tabel 4.3. didapatkan hasil bahwa sebagian besar responden memiliki pengetahuan baik tentang makanan cepat saji (Fast Food) yaitu sebanyak 33 orang $(47,8 \%)$, hasil penelitian ini serupa dengan penelitian yang dilakukan oleh Islamiyati $(2014)^{9}$ diketahui bahwa tingkat pengetahuan mengkonsumsi makanan dan minuman instan siswa Kelas IX Program Keahlian Jasa Boga SMK Negeri 6 Yogyakarta sangat tinggi. Sedangkan menurut Hasibuan $(2014)^{10}$ berdasarkan hasil penelitian pada siswi SMAN 1 Barumun tahun 2014 dapat diketahui bahwa siswi memiliki pengetahuan baik terhadap makanan siap saji yaitu sebanyak 97,4\%, dan remaja putri SMAN 1 Barumun $100 \%$ jawaban mengetahui makanan siap saji. Pada penelitian yang dilakukan oleh Tarigan $(2012)^{7}$ dapat diketahui bahwa mahasiswa memiliki pengetahuan baik tentang konsumsi makanan cepat saji yaitu sebanyak $86,3 \%$. Pengetahuan yang baik juga didapatkan dari penelitian Lyo (2013) ${ }^{11}$ dari hasil penelitian ini hampir seluruh responden mempunyai pengetahuan yang baik dari jawaban yang mereka berikan lewat kuesioner. Hasil serupa juga didapat dari penelitian Wulansari (2009) ${ }^{12}$ didapatkan bahwa sebagian besar mahasiswa PSPD UIN Syarif Hidayatullah Jakarta memiliki pengetahuan baik tentang fast food. Sebagian responden dalam penelitian ini memiliki pengetahuan sedang tentang makanan cepat saji (Fast Food) yaitu sebanyak 29 orang (42,0\%), dan pengetahuan rendah tentang makanan cepat saji (Fast Food) yaitu sebanyak 7 orang $(10,1 \%)$. Berdasarkan observasi di lapangan pengetahuan pelajar tentang makanan cepat saji (fast food) didapatkan dari hasil browsing di internet dan melihat tayangan iklan tentang makanan cepat saji (fast food) baik itu di majalah, televisi dan berbagai media lainnya.

\section{Sikap Pelajar Tentang Makanan Cepat Saji (Fast Food)}

Berdasarkan tabel 4.4. didapatkan hasil bahwa sebagian besar responden memiliki sikap baik terhadap makanan cepat saji (Fast Food) yaitu sebanyak 38 orang $(55,1 \%)$, hasil ini serupa dengan penelitian yang dilakukan oleh Lyo (2013) $)^{11}$ Berdasarkan hasil penelitian yang dilakukan total responden yang menunjukan sikap baik sebesar 71 responden $(100 \%)$ dan tidak ada yang bersikap tidak baik. Hasil tersebut juga sejalan dengan penelitian yang dilakukan oleh Gea (2014) $)^{6}$ sikap responden dengan kategori baik yaitu sebesar 44,6\% . Sikap baik tersebut dipengaruhi oleh dukungan sosial yang diterima oleh responden. Berdasarkan penelitian yang dilakukan oleh Wulansari (2009) ${ }^{12}$ didapatkan bahwa sebagian besar mahasiswa PSPD UIN Syarif Hidayatullah Jakarta memiliki sikap yang baik terhadap makanan cepat saji (fast food. Demikian juga dengan penelitian yang 
dilakukan oleh Tarigan (2012) ${ }^{7}$ juga dapat diketahui bahwa mahasiswa memiliki sikap baik tentang konsumsi makanan cepat saji yaitu sebanyak $62,1 \%$. Sebagian responden dalam penelitian ini memiliki sikap sedang terhadap makanan cepat saji (Fast Food) yaitu sebanyak 29 orang $(42,0 \%)$, dan sikap rendah terhadap makanan cepat saji (Fast Food) yaitu sebanyak 2 orang (2,9\%). Berdasarkan observasi di lapangan sikap pelajar terhadap makanan cepat saji (fast food) di pengaruhi oleh interaksi dengan banyak orang sehingga pelajar mudah dipengaruhi oleh lingkungan sekitar, iklan dimedia cetak maupun elektronik mempunyai pengaruh besar terhadap sikap pelajar dalam memilih makanan cepat saji (fast food), karena tujuan utama dari iklan tersebut adalah membawa pesan-pesan yang berisi sugesti yang dapat mengarahkan pelajar untuk mengkonsumsi makanan cepat saji (fast food).

\section{Tindakan Pelajar Tentang Makanan Cepat Saji (Fast Food)}

Berdasarkan didapatkan hasil bahwa sebagian besar responden memiliki frekuensi konsumsi sering dalam mengonsumsi makanan cepat saji (Fast Food) yaitu sebanyak 41 orang $(59,4 \%)$, hasil ini serupa dengan hasil penelitian yang dilakukan oleh Lyo $(2013)^{11}$ dari hasil penelitian dapat dilihat bahwa tingkat konsumsi fast food pada mahasiswa tinggi, meskipun pada pembahsan sebelumnya diketahui mahasiswa memiliki pengetahuan dan sikap yang baik. Sebagian responden dalam penelitian ini memiliki frekuensi konsumsi jarang terhadap makanan cepat saji yaitu sebanyak 17 orang responden Dan sisanya memiliki frekuensi konsumsi sangat sering mengonsumsi dalam makanan cepat saji (Fast Food) yaitu sebanyak 11 orang (16\%), hasil ini serupa dengan hasil penelitian Tarigan $(2012)^{7}$ diketahui bahwa sebagian besar mahasiswa memiliki frekuensi konsumsi makanan cepat saji sangat sering yaitu sebanyak 37,9\%. Menurut Irasmi (2012) ${ }^{13}$ Peran keluarga, Kemajuan ilmu pengetahuan serta teknologi telah membawa dampak yang cukup besar terhadap perubahan perilaku makan mahasiswa terhadap jenis makanan dan minuman. Dimana keluarga merupakan tempat mendapatkan pendidikan dasar baik itu orang tua ataupun keluarga yang lainnya akan mempenagaruhi perilaku anggota keluarga yang lain termasuk seorang anak yang didik sejak masih kecil akan tercermin perilaku tersebut sampai anak itu beranjak dewasa. Berdasarkan observasi di lapangan tindakan pelajar terhadap makanan cepat saji di pengaruhi oleh banyaknya tersedia tempat-tempat penjualan makanan cepat saji (fast food) di lingkungan sekitar sekolah, sehingga memberikan kesempatan pada pelajar untuk sering mengkonsumsi makanan cepat saji (fast food).

\section{Hubungan antara pengetahuan dengan tindakan dan sikap dengan tindakan.}

Berdasarkan tabel 4.6 didapatkan hasil bahwa dari 33 orang responden yang memiliki pengetahuan baik, ada 20 orang responden yang mempunyai frekuensi konsumsi makanan cepat saji (fast food) sering. Hal ini disebabkan oleh tersedianya sejumlah fasilitas penyedia makanan cepat saji di sekitar lingkungan sekolah. Demikian pula dengan responden yang memiliki sikap baik terhadap makanan cepat saji (fast food) juga memiliki frekuensi konsumsi makanan cepat saji sering. Hal ini dapat dilihat seperti pada tabel 4.7 dimana dari 38 orang responden yang memiliki sikap baik terhadap makanan cepat saji (fast food), ada 25 orang responden yang mempunyai frekuensi konsumsi makanan cepat saji sering. Untuk mengurangi dampak negatif dari mengonsumsi makanan cepat saji hendaknya responden mengimbanginya dengan makanan tinggi serat seperti sayuran dan buah-buahan, dan jangan lupa untuk berolahraga. 
Anshari Z : Gambaran Pengetahuan, Sikap, dan Tindakan Pelajar, Tentang Makanan Cepat Saji (Fast Food) di MTs Al-Manar Medan

\section{DAFTAR PUSTAKA}

Veranita. Hubungan Frekuensi Konsumsi Makanan Cepat Saji dengan Status Gizi. Medan: Universitas Sumatera Utara; 2014.

Seto S. Pangan dan Gizi. Bogor: CV sagung seto; 2001.

Sulistyoningsih H. Gizi untuk Kesehatan Ibu dan Anak. Yogyakarta: Graha ilmu; 2012.

Amaliah dan Murdiati A. Panduan Penyiapan Pangan Sehat untuk Semua. Ed 2. Jakarta: kencana prenada media group; 2013.

Sihaloho NM. Faktor-Faktor yang Memengaruhi Pola Pemilihan Makanan Siap Saji Modern (Fast Food) pada Pelajar di SMA Swasta Cahaya Medan Tahun 2014. Medan: Universitas Sumatera Utara; 2012.

Gea RN. Gambaran Tayangan Iklan Fast Food (Makanan Siap Saji) di Televisi dan Kebiasaan Makan Fast Food (Makanan Siap Saji) dan Kejadian Obesitas pada Pelajar di SMA Swasta Cahaya Medan Tahun 2013. Medan: Universitas Sumatera Utara; 2014.

Tarigan EF. Pengetahuan, Sikap dan Tindakan Mahasiswa Fakultas Kedokteran Universitas Sumatera Utara tentang Konsumsi Makanan Cepat Saji. Medan: Universitas Sumatera Utara; 2012.

Yuliarti N. Awas! Bahaya Dibalik Lezatnya Makanan. Yogyakarta: ANDI; 2007.

Islamiyati AN. Perilaku Konsumsi Makanan Dan Minuman Instan Pada Siswa Kelas XII Program Keahlian Jasa Boga SMK Negeri 6 Yogyakarta. Yogyakarta: Universitas Negeri Yogyakarta; 2014.

Hasibuan R. Perilaku Makanan Siap Saji (Fast Food) Dan Kejadian Obesitas Pada Remaja Putri di SMA Negeri 1 Barumun Kecamatan Barumun Kabupaten Padang Lawas Tahun 2014.Medan: Universitas Sumatera Utara; 2014.

Lyo AMR. Perilaku Mahasiswa Angkatan 2013 Fakultas Kedokteran Universitas Sam Ratulangi Terhadap Makanan Cepat Saji. Manado: Universitas Sam Ratulangi; 2013.

Wulansari L. Pengetahuan, Sikap, Dan Perilaku Mahasiswa Program Studi Pendidikan Dokter Universitas Islam Negeri Syarif Hidayatullah Jakarta Tentang Makanan Cepat Saji (Fast Food) Tahun 2009. Jakarta. Universitas Islam Negeri Syarif Hidayatullah; 2009.

Irasmi. Perilaku Mahasiswa Dalam Memilih Jenis Makanan Dan Minuman Di Makassar Town Square. Makassar: Universitas Hasanuddin; 2012 